\title{
複層化セル・オートマトンによる地方都市の解析モデル \\ AN ANALYSIS PROCEDURE OF LOCAL MUNICIPALITY BY USING A MULTI-LAYERED CELLULAR AUTOMATA
}

\author{
本 間 俊 雄*1, 友 清 貴 和*2, 松 永安光*3，豊田 星二郎*4，福 永 知 哉*5 \\ Toshio HONMA, Takakazu TOMOKIYO, Yasumitsu MATSUNAGA, \\ Seijiro TOYODA and Tomoya FUKUNAGA
}

\begin{abstract}
Japanese population is predicted to start decreasing early this century. This inexperienced phenomenon will most drastically appear in local municipalities. In order to establish planning for such municipalities facing this new phase of development, more accurate demand estimation, that is totally different from the conventional empirical method, will become indispensable. Therefore we propose a numerical procedure using a multilayered cellular automata with the cells of the layers interacting each other. The cell is a population set in the region. One layer is an age composition of the population. The basis of our procedure guesses the population fluctuation by the state transfer relations (local rules) between each cell. In order to verify the validity of the numerical procedure with the multi-layered cellular automata, we analyze Kagoshima City as a sample. Firstly, a function of state transfer is defined from the characteristic of the population fluctuation using equations with various computational parameters. The state transfer relation is decided from the measurement geography. The computation results are evaluated by their chronological conformity in comparison with the statistics data. Finally, the parameters that showed the best conformity are used for the future estimation of the population in urban and regional planning with a charm project. Moreover, the tendency for the population fluctuation of the local municipalities is investigated by analyzing the value of the computation parameter.
\end{abstract}

Keywords : Urban and regional planning, Population fluctuation, Migration, Multi-layered cellular automata, State transfer rule 都市·地域計画，人口変動，人口移動，複層化セル・オートマトン，状態遷移規則

\section{1.はじめに}

我が国では、すでに生産年齢人口がピークを過ぎており、総人口は 2006 年を境に減少に向うり。従来の都市計画では、あるエリア(一般には各自治体) の人ロフレームを設定し、それに見合う都市施設の整備量を決定するという 手順が取られてきた。この手順を続ける限り、人ロフレームの堿少は都市に 括ける各種需要の減少を示唆する。もちろん都市における各種需要は、租税 基般や消費の量と質など経済的要因にも依存する。しかし、都市全体の人口 フレームだけでなく年齢別人口の地域における増堿や域内人口の移動は、各 種需要に大きく影響することが分かっている2。

すなわち人口減少に直面している現況において、狭いエリア毎の人口変動 を予測し、それに見合った都市における各種需要を推定することは、持続可 能な活性化した都市・地域計画を進めるに当たって重要なポイントである。年 齢階釉別人口変動の推定では、染谷による方法 ${ }^{3)}$ がよく知られている。しか し、一定の人口規模の既存都市を取り上げ、小規模な域内人口移動も含めた 男女別·年齢構成別人口変動の推定を試みた解析モデルの提示例は、著者らの 知る限り見られない。

本論文の目的は、このような人口変動を伴う一定地域の人口の分布と構造 を複雑系と捉え、解析モデルをセル・オートマトン(cellular automata：CA) 基ついて構筑し、地方都市の人口状況とその特徽を把握する基本的な数理モ デルを提案することである。CA は、従来の現象をマクロに定義した微分方 程式などの関倸式により全体像を捉える力法とは異なり、セル間の規則の積 み上げからセル間の相互作用を通して全体像を把握しようとする方法である。 一般に人の行動は微分方程式などの関係式で表現しきれない。表現できたと
しても解くことができないと考えた方が自然であろう。ここに本論文では多 様性を許容する CA と人口変動を結び付ける。提案する数理モデルの有効性 が確認されれば、地方都市の人口分布・人口構造の推定だけでなく、その地域 が持つ住民行動の特徵も調べられることも期待される。さらには各種需要量 に見合った都市施設の整備目標を推測することも可能であり、魅力ある地方 都市の再生と活性化のための基礎データとなる。

CA を用いた都市に関する解析モデルの既往の研究は、大きく二つに分け られる。一つは、定義した近傍内の状態遷移 (state transfer) の規則によりモデ ルの状態を追跡し、得られた状態と実現象の状態を対比することで方法論を

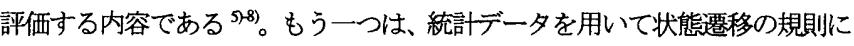
関する計算パラメータを同定し、その值により近未来を推定する内容である 91.10)。本研究で住後者に分類される方法を採用する。なお、CA の他に遺伝的 アルゴリズムと複合させたモデル 11 や CA と類似のマルチエイジェントによ るモデル ${ }^{12)}$ の論文もあり、CA 関連の研究が幅広くはじめられている。

本論文の構成は次の通りとする。まず、採用する CA を説明する。特に、 男女別·年齢構成別人口変動に着目した都市内の狭いエリアをセルとして置 き換え、そのセルを複層化する必然性と定義を示す。状熊遷移規則は自律規 則と近傍規則に分ける。近傍規則に関しては人口移動に注目し、代表的な要 因を数式化する。数式内の各種計算パラメータは各地方都市の統計データに より決める。この数理モデルを用いた都市の解析例では鹿览島市の中心市街 地を採り上げ、パラメータの決定と評価法を示し、近未来の小規模域内の人 口変動を予測する。これらの結果から、提案した CA モデルによる解析手順 の有効性と発展性を検討する。

\footnotetext{
*1. 鹿児島大学工学部建築学科 助教授・工博

*2 鹿児島大学工学部建築学科 教授. 工博

*3 鹿児島大学工学部建築学科 教授・M.A.

*4 玉置アトリ工 修士(工学)

*5 イクス・アーク都市設計 修士(工学)
}

Assoc. Prof., Dept. of Architecture \& Architectural Eng., Faculty of Engineering, Kagoshima Univ., Dr. Eng.

Prof., Dept. of Architecture \&. Architectural Eng., Faculty of Engineering, Kagoshima Univ., Dr. Eng.

Prof., Dept. of Architecture \& Architectural Eng., Faculty of Engineering, Kagoshima Univ., M. Architecture

Tamaki Architectural Atelier, M. Eng.

X-Arc Urban Architects Inc., M. Eng. 


\section{2. セル・オートマトンを用いた計算モデル}

\section{1 梅層化セル・オートマトン}

CA の一般事項の説明は文献4)に任せ、ここではセル内を複層化する著者 らのモデル概念をまとめる。一つのセル内に複数の状態量を持たせた都市の CA モデルは既にありク、都市という多様な情報を処理する上でその考え方は 先見的である。本論文では別の視点で複数の状態量を追跡可能とさせるため、 セル内に層を設定する。特に人口変動に関しては、男女別、年齢構成別など 相互に関連する情報量が多くなるため、複層化することで情報の効率的な分 類と捛作を可能とする。以下にある地方都市の人口変動を例に説明する。

図 1[A]に示す不規則な地図上のある地方都市をセルの集合により置き換え る。セルの配置法はいろいる考えられる。地図上を規則正しく区切る場合や 整列したセルの集合に写像させてもよい。ただし、各セルは学区あるいは行 政区など、その地域の人口情報を表現し得るように分けなければならない。 これらのセルは互いにネットワーク関係(状態遷移規則)を持つネネットワー ク関係とは隣接したセルとセル間に単純な規則を設定することで与えられる。 その結果系全体が通常の二次元 $\mathrm{CA}$ モデルを構成する(同図 $[\mathrm{B}]$ )。しかし、都 市の人口変動をモデル化する場合、多様な要素·要因があり、一つのCA では 表現しきれない。しかも複数の CA を構成したとしても、各モデルのセルは 独立した現象を発現するのではなく、モデルを飛ひ越して対応するセルや隣 接するセルから相互に影響を受ける(同図[C])。そこで同図[D]に示す CA を 想定する。これは各 CA 一つひとつのセルを層とし、対応する層の集合を一 つのセルと置く。これが複層化 CA モデルのセル基準である。通常、層方向 の関係と隣接セルとの関係を同じと扱えないにもかかわらず、全て同じネッ トワークと解釈し、無理した複雑に入り込む規則を構成して三次元 CA など の高次元モデルを設定していた。これに対し本論文で示すアイデアは、CA に層という新しい概念を取り入れ、層方向のデータの流れと隣接セルとのデ 一夕の流九を情報内容の関連性から別に処理し、多面的な情報の位置づけを 明確にする。つまり従来のCA モデルと比べ、複層化 CA は与える規則と得 られる情報の整理が容易で、情報内容に沿った現象の理解を促進させる。

\section{2 数理モデル}

上述の複層化 CA の概念を具体化させるため、 $N$ 個に分割したモデルにお ける任意のセル $i$ 内の状態量 $P$ を次式のように定義する。

$$
\begin{aligned}
& P_{i(k)}=P_{i(k)}(t), \quad P_{i(k)^{t_{n}}=P_{i(k)}\left(t_{n}\right) \quad(n=1,2,3, \cdots)} \\
& P_{i(k)^{t_{n}}}=\sum_{r=1}^{L} P_{i(k)}^{r}{ }^{t_{n}}
\end{aligned}
$$

ここで、 $t:$ 時間ステップ、 $k:$ セル内の指定した層、 $L: k$ 層内の区分(状態 量の種類)である。式(1)は状態量が $t$ の関数であること及び $t$ の離散量の定義 を与える。式(2)に示すように各層は複数の状態量 1～L が存在し，その状態 量が集まり層を形成する。この数は任意の個数を採る。また、層内を入れ子 状にすると更なる拡張も可能になる。例えば、層のモデルを年齢別構成にす ると、各層に男女の人口区別が加えられ、新たに職種別という区分も導入で きる。なお、状態量 P はセルの面積を考慮した密度とした方が扱いやすい。

次に、次ステップへ推移するときのセル内の層と層およびセルとセ ル間に㗢く規則すなわち状態遷移規則は次のように自律規則 $\pi$ と近 傍規則 $\psi_{j} \quad(j=1, \cdots, \ell . \ell:$ 対象セルの近傍内セル数)に分けて考える。

$$
\begin{aligned}
& P_{i(k)}{ }^{I_{n+1}}=\pi\left(P_{i(k)}{ }^{l_{n}}, \alpha_{\left.i(p q)^{l_{n}}, \vartheta_{i(p q)}\right)} \quad(p, q=1,2, \cdots, K)\right.
\end{aligned}
$$

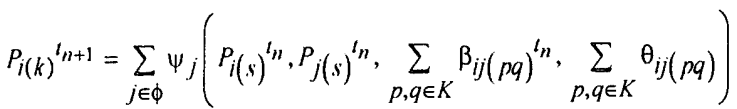

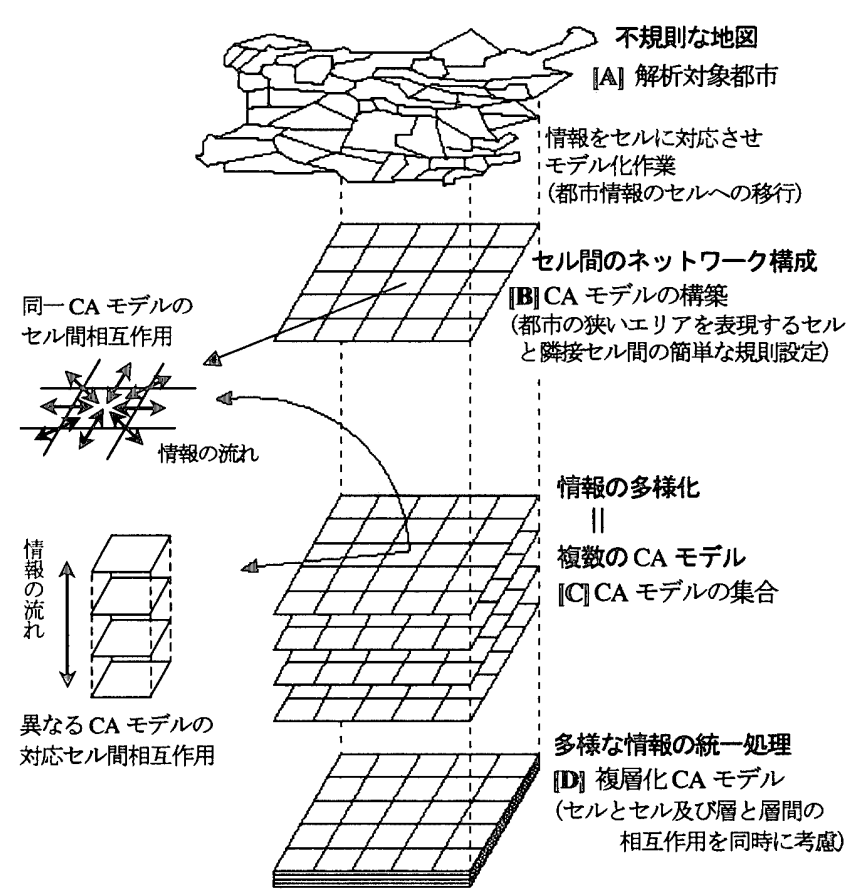

図 1 複層化セル・オートマトンモデルの概念図

ここで、 $\alpha_{i(p q)}{ }^{t_{n}}: i$ セル $p, q$ 層間の影響係数、 $\vartheta_{i(p q)}: i$ セル $p, q$ 層間の閥值、

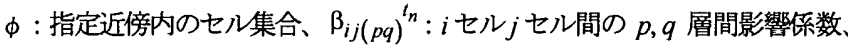
$\theta_{i j(p q)}: i$ セル $j$ セル間の $p, q$ 層間闇値、 $K$ : 対象セルの総層数である。なお、 状態量 $P$ は人口(密度)に限定する必要はない。また、式(3),(4)の $P_{i(k)}$ は状態 量の内容や取り扱い方により層内区分 $P_{i(k)}^{r}$ で考えることもある。

\section{3. 暗市解析モテ゚ル}

\section{1 人口変動}

人口は、出生と転入によって増加し、死亡と転出によって減少する。これ を式に表すと人口学的方程式という次式で表せる ${ }^{133}$ 。

増加人口 $=$ (出生-死亡) + (転入-転出)

$$
=\text { 自然増加 }+ \text { 社会増加 }
$$

通常、現在から 5 年後の人口は、現在の人口に今後 5 年間の増加人口を加え ることによって求められる。5 年間の増加人口は自然増加(出生と死亡の差) 及ひ社会増加(転入と転出の差)の予測から得られる。人口変動モデルの状態 遷移規則では、この自然増加と社会増加のみで考える。個々のセルは人口ピ ラミッドと同じく、 5 才間隔年齢別 $(K=20: 0 \sim 100$ 歳までを区分) の層内に男 女別 $(L=2)$ 人口という $20 \times 2(=K \times L)$ の情報ボックスを準備する。このような 層の導入により、自然増加と成長による層の繰り上がりがセル内の層間に作 用する式(3)に対応した自律規則となる。社会増加は各セルの層間に作用する 式(4)に対応した近傍規則である。

自律規則では、既に人口推計学により確立されたコーホート要因法を参考 に計算する。これに対して都市の人口変動を支配する要因は近傍規則による 人口移動である。人口移動の行動内容を分析すると多くの要因が考えられる。 ここでは限定した $5 つ の$ 行動パターンを採り上げる。これら本論文で用いる 状態遷移規則の内容は図 2 の通りとする。

\section{2 自律規則}

自律規則はコーホート要因法に従う。コーホートとは、同期間に出生した 年齢階級集団(層)のことをいう。コーホート要因法は、その集団毎の時間変 


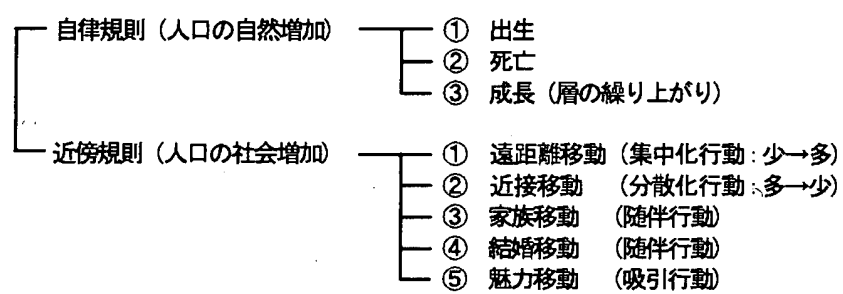

図 2 状態遷移規則一覧

化を軸に人口変化を捉える計算法であり、人口の時間経過による変化を層每. 男女別に出生と死亡及び移動に基づき求める。ただし、移動に関しては近傍 規則で扱うため、自律規則には反映させない。各層はある確率で死亡して人 口が隇少する。また、層の約半分が女性であり、同じくある率に従って子供 を出産する。その子供たちは新たな0４才という層を構成する。このような 自然増加を全ての層每に 5 年間隔で推計する。さらに、各層は 5 年後に $1 つ$ 上の年齢層に繰り上がる。これらの自律規則の計算パラメータは次の通りで あり、解析対象地城の統計データを用いる。

(1) 死亡 : 性.5 才階級別生存率、(2) 出生: 女子の 5 才階級別出生率、(3) 出 生性比 : 出生児の男女比

\section{3 近倿規則}

社会增加の当事者である移動者は、目的地選択行動を様々な条件と不完全 な情報の下に決める。したがって、全ての内容を把握し規則化することは無 理がある。ただし、条件や情報に関わる主な物理的要因は、商業·会社·学校· 住宅の設置や廃止であり、施設の事業者は、需要つまり人口密度を指標に計 画すると仮定する。すなわち移動者の指標は、事業者が行った「人口密度を 指標に目的地を選択する」という手順を踏襲すると想定する ${ }^{14) 。 こ の よ う な ~}$ 計量地理学の視点の下、人口密度を指標とする近傍規則を定義する。なお、 全国の都道府県内移動理由別の調查によると住宅事情·結婚・就業関係の順に 移動理由が多い ${ }^{14,15)}$ 。これらの移動全てを閒接的に表現するため、図 2 で示 したように以下の5つの行動パターンを仮定する。

(1)遠距離移動 (2)近接移動 (3)家族移動 (4)結婚移動 (5)魅力移動 これらの移動行動は(1)と(2)、(3)と(4)、及び(5)の3つに分類することができる。 (1),(2)は口口集中化と分散化行動であり、(3),(4)は随伴行動、(5)は魅力による 吸引行動である。(1)〜4)では、セル自身の各層と、近接もしくは遠方のセル の各層における状態量とを比較し、その大小関係に基づいてお互いの各層の 人口を增減させる。コーホート要因法では人口移動を純移動率という値を用 い、転入人口を自地域の層人口より求めていて、転入先と転出先に対寸る 2 つの地域の直接的な人口移動を考えない。すなわち本 CA の近傍規則は計量 地理学で行われる人口移動の移動マトリクス法 ${ }^{14}$ に近く、実際の出と入の移 動量を考慮したものとなっている。この近傍規則にまとめた移動行動と自然 增加のみのコーホート要因法を相互に補うことで、ある程度現実に近い現象 が再現できると考える。以下に仮定した各移動行動の数式化を試みる。

遠距離移動 図 3a.に示すように人は人口の集中しているところに敢えて集 まる集中化傾向がある。このような移動行動には、しばしば遠距離の移動が 伴いかつ距離による減衰傾向が存在し、人口集中地区の魅力と移動距離の耐 方を考慮に入れた選択がなされている。ここで規則設定に用いたのが、幾つ かの選択肢群の中で、もっとも効用が高い案を選ぶというモデルであり、移 動数をこの選択の和と定義する。移動数は出発地の放出性.目的地の吸引性. お互いの距離·移動量に関係し、系全体においてその総和が零であることを保 障する均衡因子の積の形で表される。これにより、以下のような規則を設定 する。

$$
\begin{aligned}
& P_{i(k)}^{t_{n+1}}=P_{i(k)}^{t_{n}}+\sum_{j \notin \phi_{a}}\left(\frac{P_{j(k)}^{t_{n}}}{P_{i(k)}^{t_{n}}}\right)^{\delta} d_{i j}{ }^{-\mu} \quad\left(i \in \phi_{a}, \mu \geq 0\right) \\
& P_{j(k)}^{t_{n+1}}=P_{j(k)}^{t_{n}}-\sum_{j \in \phi_{a}}\left(\frac{P_{j(k)}^{t_{n}}}{P_{i(k)}^{t_{n}}}\right)^{\delta} d_{i j}{ }^{-\mu} \quad\left(i \notin \phi_{a}, \mu \geq 0\right)
\end{aligned}
$$

ここで、 $\delta:$ 人口比パラメータ、 $\mu:$ 距離パラメータ、 $d_{i j}$ : セル $i$ とセル $j$ 間の物理的な距離 である。流失するセルの $k$ 層の人口密度と流入するセルの $k$ 層の人口密度比の $\delta$ 乗、両セル間距離の $\mu$ 乗の逆数の積に比例した人口が お互いの $k$ 層間で移動する。集合 $\phi_{a}$ は遠距離移動により人口が流入するセル の範囲を規定する。セルの範囲は人口密度の高い順にセルを順番付けてその 順位により与える。移動者が比較的広い視野で、なるべく移動距離を少なく しつつ、人口密度の高い地域に移動する規則となっている。つまり反は移動 者の環境条件への意識 $\mu$ は移動距離への敬遠の程度を表す。

近接移動 近接移動は遠距離移動とは相反する移動行動であり、図3b.に示す ように近接地域への分散化傾向を意味する。この行動に対して以下の規則を 与える。

$$
P_{i(k)}^{t_{n+1}}=P_{i(k)}^{t_{n}}+\sum_{j \in \phi_{b}}\left[\left(\overline{P_{j(k)}^{t_{n}}}\right)^{\gamma}-\left(P_{j(k)}^{t_{n}}\right)^{\gamma}\right]
$$

ここで、 $\gamma:$ 人口比パラメータである。近接するセルによって作られた集合 $\phi_{b}$ において、セル $i$ の 層の人口密度はその $\gamma$ 乗に比例する速度で、対象近 傍の $k$ 層の平均人口密度 $\overline{P_{j(k)}^{t_{n}}}$ に近づく。この規則はある任意の範囲の層を 決め、近傍集合 $\phi_{b}$ のセルに適用する。移動者が多くの情報・限定された条件 の下に良い環境を求めて比較的近距離の移動をする。ここでは良い居住環境 を、慣れ親しんだ周辺地域における人口が集中していない地区と仮定してい る。 $\gamma$ は移動者の目的地選択に対する良い環境一の意識の程度を表現する。 随伴行動 随伴行動には家族移動之結婚移動がある。日本の人口の約 $90 \%$ に 当たる 1 億 1000 万人は家族生活を送っている ${ }^{(4)}$ 。したがって、人口移動にお いて家族のことを無視するわけにはいかない。転勤なと移動の主体が世带主 であったとしても、その両親・配偶者·子供などの扶養家族がそれに随伴する 形で移動する。統計データによると転勤における単身赴任の率は全体の半分 以下である。遠距離移動と近接移動が移動者本人に注目した規則であったの に対し、この規則は本質的に異なる。世带主に該当する層の移動行動に引き ずられる形で、他の層の人口が変化する受身的な様相である。この規則によ り移動する子供や老人などは、自身の層の変化に注目するのではなく、間接 的に世帯主の層の人口分布を参照して行動を起こす。したがって、家族自体 の移動現象はそれほと顕著に発生しないものの、遠距離移動・近接移動などと 複合して作用する。結婚移動は家族移動と本質的に同じ現象である。しかし、 家族移動と別の籍囲の層を対象と寸る。このような現象の規則は次のように

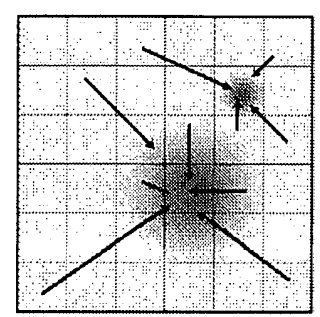

a. 集中化傾向(遠距離移動)

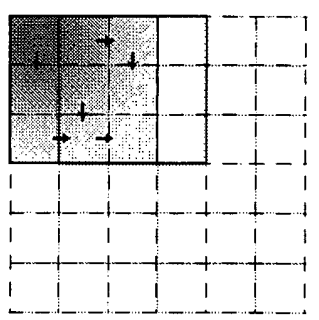

b. 分散化傾向 (近接移動)
図3 CA モデルの集中化と分散化の移動行動 儿口密度、濃 : 高、㷋 : 低 
設定する。

$$
P_{i(k)}^{t_{n+1}}=P_{i(k)}^{t_{n}}+\alpha_{k} M_{i(m)}^{t_{n}} \quad(k \neq m)
$$

ここで、 $\alpha_{k}$ : 移動パラメータ である。随伴行動の増减対象となる $P_{i(k)}^{l_{n}}$ は、 セル $i$ のある層の世帯主 $P_{i}^{r}(m)^{l_{n}}$ の 5 年間における移動数 $M_{i(m)}^{l_{n}}$ に比例して、 そのセルの妻·子供·親などに当たる層が増堿する。妻·子供·親などにはそれ ぞれ移動率 $\alpha_{k}$ が設定でき、世帯主の移動数 $M_{i(m)}^{\prime n}$ に対する転勤、単身赴任 等の割合が考慮できる。系全体で移動数の総和が零になることは他の規則で も保障するため、この規則により発生する世帯主の移動数に移動率 $\alpha_{k}$ を乗じ た值の総和も零になる。ただし、層毎の $\alpha_{k}$ の決定はパラメータが多くなりす ぎるため、層の範囲をあらかじめ定め平均的な值を用いる。

魅力行動 人口移動に強く影響を及ぼす要因の中には、人口密度で置き換え ができない要因もある。その一つに行政などによる大型団地の開発(魅力事 業)が上げられる。本論文では簡易的に、建設されると同時に大量の人間が移 り住むということ、その魅力は開発終了後時間と共に減少する、という観点 から次のような規則を設定する。なお、この式は大規模商業施設や大型病院 の隣接地域に人が移動する現象にも応用できる。つまり魅力としての流入現 象をモデル化したものである。

$$
\begin{aligned}
& P_{i(k)}^{t_{n+1}}=P_{i(k)}^{t_{n}}+\frac{\rho}{100} H \sum_{j \notin \phi_{C}} P_{j(k)}^{t_{n}} \\
& P_{j(k)}^{t_{n+1}}=\left(1-\frac{\rho}{100} H\right) P_{j(k)}^{t_{n}} \quad\left(j \notin \phi_{C}\right) \\
& H=1-(t / T)^{2}
\end{aligned}
$$

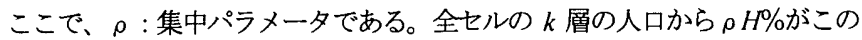
団地の $k$ 層に移り住む。魅力度 $H$ は建設当初 1 で、拡張計画が終わる $T$ 年後 を基準に魅力がなくなるとする。この規則は人口密度に左右されない魅力と いう別の指標を用いている。 $\phi_{c}$ は魅力事業を行うセル集合である。なお、本 論文では距離减衰を考慮していないが、式に追加することも可能である。

\section{4 計算手順}

以上の複層化 CA による数理モデルを用いて、具体的な人口推計の方法を 示す。セルはフィールド内の他のセルあるいは近傍のセルと自己の状態值と を比較し、上述した状態遷移規則に従って情報の受け渡しをする。この、フ ィールド=地方都市の限定した地域、セル＝小規模地域、情報=人口（人口密 度・区分)、情報の受け渡し(規則)=セル内の成長・各種人口移動 をモデルと した計算手順は以下の通りである。

(1) フィールド(解析対象領域)を決め、セルを設定する。その際、不規則な地 図を格子状のセルにモデル化し、実面積を算出する。

(2) 地方都市の統計データから、モデル化したセルに対応する人口表(層・区 分）を作成する。

(3) 統計データからセルに初期值として地域別・年齢別・性別の人口、男女の年 齢別死亡率、女子の年齢別出生率、セル間距離を与える。

(4) セル間·層間の相互作用を規定する状態遷移規則を単独で試行し、計算パ ラメータの範囲を決める(式(3),(4)における影響係数, 閑值範囲の決定。具 体的には近傍規則にかかわる計算パラメータの範囲を推定する)。

(5) 計算結果から規則及び含まれる計算パラメータの種類・值·組合せによる 挙動特性を把握する。

(6) 計算結果と過去の統計データと照合し、再現性が高いパラメータを抽出す る(人口変動の推移データと計算データによる評価值計算 (3.5 で説明))。

(7) 計画イベント(魅力事業)による人口移動を(6)で調べた幾つかの再現性の 高い計算パラメータを用いて将来予測する。
以上(1)〜7)の手順により、対象都市を解析し、今後のあるいは新たな計画に よる人口移動の予測を行う。なお、計算手順では次の処理をする。まず各セ ル各コンホートで近傍規則を同時に実施する。その結果、系内の人口増减が 生じた場合、補正を各セルの人口に忘じて行い、自律規則の実施に移る。

\section{5 再現性の評価}

解析対象フィールドを $N$ セルにモデル化し、統計(実)データを初期值とし て人口分布と人口構造を追跡する。この解析結果の全 $N$ セルの人口データを 1 ステップ毎に評価し、各セルに評価値を与える。この $t_{n}$ ステップの $i$ セルの 評価値は一致度 $\sigma_{i}^{t_{n}}$ として次式で与える。

$$
\sigma_{i}^{t_{n}}=\frac{1}{A^{t_{n}}} \sqrt{\frac{1}{K L} \sum_{k=1}^{K} \sum_{r=1}^{L}\left(P_{i}^{r}(k)^{t_{n}}-\tilde{P}_{i}^{r}(k)^{t_{n}}\right)^{2}}
$$

ここで、 $\tilde{P}_{i}^{r}(k)^{t_{n}}: i$ セル $k$ 層の $r$ 区分 $\left(r=1\right.$ :男，2:女） $t_{n}$ ステップの実デー 夕、 $A^{t_{n}}:$ ，層内の一区分当たりの平均人口密度(系の総人口 $/ K / L N /$ 系の総面 積) である。全セルの一致度 $\sigma_{i}^{\prime n}$ の総和すなわち次式をそのステップの系全 体における評価値 $\omega^{t_{n}}$ とする。

$$
\omega^{t_{n}}=\sum_{i=1}^{N} \sigma_{i}^{t_{n}}
$$

この式によりステップ毎に評価値が得られる。計算結果と実データが完全に 一致する場合は $\omega^{t_{n}}=0$ である。つまり各セルの一致度が小さいほど再現性 が高いと考える。しかし、一致度が小さい場合でもある層において計算結果 と㥶データとが極端にずれることがある。こような状況を回辟するため、各 セルの各層男女別の計算結果と実データとの差の平方和に対する正の平方根 が既定值を超えるときに、一致度 $\sigma_{i}^{t_{n}}$ にペナルティ(penalty)を加算する。こ の各層・区分每のペナルティ付加の規定值は次式で与える。

$$
\lambda_{i(k, r)}^{l_{n}}=\frac{K L}{\tilde{P}_{i}^{t_{n}}} \sqrt{\sum_{k=1}^{K}\left(P_{i}^{r}(k)^{t_{n}}-\tilde{P}_{i}^{r}(k)^{t_{n}}\right)^{2}}
$$

ここで、 $\tilde{P}_{i}^{t_{n}}: i$ セル $t_{n}$ ステップの総状態量の実データ である。

総合的な評価では次のように考える。各ステップの評価值の絰和が最も小 さいときに用いた計算パラメータの試行が最もよい再現性があると判断する。 ただし、都市解析上、限られた数のルールを設定し、対象都市が平均的な振 る舞いを発現すると仮定しているため、 $\omega^{t_{n}}=0$ あるいは零に近い值が得ら れたとしても、必ずしもその計算パラメータが対象都市を完全に再見するこ とではない。採用した計算パラメータの意味の考察、評価值 $\omega^{t_{n}}$ の比較的よ い試行による人口移動の内容を幾つか採り上げ、総合的に判断する。その上 で都市計画上の一助とすべき基礎データとして活用すべき内容である。

\section{4. 鹿児島市を例とした解析例}

4. 1 解析モデル(フィールド)

図 4 に示寸ように鹿児島市 $(1975$ 年人口 $452,584 、 2000$ 年人口 552,098 )の中 心に位置する主に人口が集中している地域 53 町丁 (1975 年人口 114,854、2000 年人口 107,608)を、格子状の $25(5 \times 5)$ セルの系にモデル化する。各セルの大 きさは約 $630 \times 630 m$ である。これは鹿児島市中心市街地の平均的な町丁がほ ぼ1〜4個入る大きさであり、それぞれの町丁は各セルにより 2つに分割され ることがないようにした。本来データの入手上、行政による町丁区画あるい は学区を基淮としたセル構成とすることが望ましい。ここで提示するCA モ デルでは見かけ上 1 つのセル面積をできるだけ同じようにし、正方形の領域 を構成する必要があったため、図 4 のように町丁区画を基準にモデル化した。 
ただし、各セルの人口と面積データより、計算に重要となる人口密度の算出 が正確に求まるため、このモデル化には問題がないと考える。また、モデル 計算を簡略化するためにこの系の内外の人口移動が平衡状態を保つと仮定す る。すなわち結果的に 25 セル内のみで人口移動が行われるものとし、25の セル間の相互作用による人口分布・人口構造の変化を推計する。

セルには人口ピラミッドと同じ 5 才間隔年齢別・男女別人口 $20 \times 2$ の層状 の情報を持たせる。セル間で近傍規則により人口を移動させながら、セル内 においても自律規則に従った人口増堿を考える。ステップ計算では 1 ステッ プ毎に各層を 1 つ上の層に繰り上げる。初期値データは 1975 年の国勢調查 データを利用する。つまり 5 年間毎の統計データを実データとした 2000 年ま での 5 ステップを追跡する。なお、計算するに当たり、ユーザインターフェ イスの利便性を考慮したGUI利用の解析システムを開発した。このように膨 大な情報を扱う CA モデルでは、システム開発が解析において本質的である。 システムの内容(機能と操作及び表示パネル)は付録で説明する。

\section{2 計算パラメータ}

遠距離移動、近接移動、随伴行動(家族移動と結婚移動)、魅力移動の式 (6)-(12)の各規則には、人口比、距離、移動、集中の計算パラメータが9 種類 ある。移動者の年齢層の範囲を入れるとパラメータの数が非常に多くなる。 ここでは表 1 に示すように移動者の年噛範囲に関しては、遠距離移動と近接 移動の層範囲を与えることができることとし、随伴行動では層範囲を固定と した(表中数值のアンダーラインは範囲固定を意味する)。これらのパラメー タの設定は地域によって異なるため、計算結果と実データを比較することで 平均的な計算パラメータの值を同定する。ここでは与えたパラメータにより どのように結果一反映されるかを観察し、各パラメータの影響力を調べる。 なお、実際のパラメータは連続的で、その候補は無数にある。しかし、全て を試行するのは不可能かつ無意味であろう。規則の特性が観察できる範囲内 で、パラメータの上限と下限及ひ離散的な值を定め、試行を実施する。この 5 つの近傍規則の単独試行として 755 のパラメータの組合せを準備した。

\section{3 システムの試行}

自律規則もしくは一つの近傍規則十自律規則による単独試行と複数の近傍 規則十自律規則による複合試行を実施する。この試行により各規則の挙動特 性が把握され、以下の結果が確認できた。ただし、随伴行動は遠距離移動と 近接移動及ひ魅力移動に付随するため単独では試行させない。

自律規則 各セル内外から転入と転出のない封鎖された状態を仮定する。各 セルの人ロピラミッドの推移は、富士山型から釷鐘型入、ならびに荍坊主型 から安定人口へ移行するという封鎖人口の状態が再現できる。また、結果と して自然増加と変わらない人口変動状態を示すセルもある。なお、得られた 結果から出生率·死亡率の統計データの利用による問題は生じない。

遠距離移動十自律規則 人口が多いセルに対しては、更に人口が集まるよう に人口比パラメータの操作で制御ができる。距離パラメータが大きいと、遠 方の人口集中セルより近接する過疎セルに人口が移る。大量に生産年齢人口 が流入したセルでは、30〜40 年後に起きる急激な高齢化現象が再現できる。 この現象は自然増加のみでは発生しない。

近接移動十自律規則 人口が多いほど平均化は速く、全てのセルで同時に平 均化が終了する。人口比パラメータがある程度大きいと平均化は速い。大き 過ぎると人口集中地区と過疎地区の間を大量の人口が行き来する振幅現象が 発生する。

近傍規則の複合十自律規則 自律規則に複数の近傍規則を同時に適用した結 果、各規則の特微が観察できる。これは近傍規則がある程度独立しているこ とを意味する。しかし少なからず他の規則による影響もあり、単独で用いた

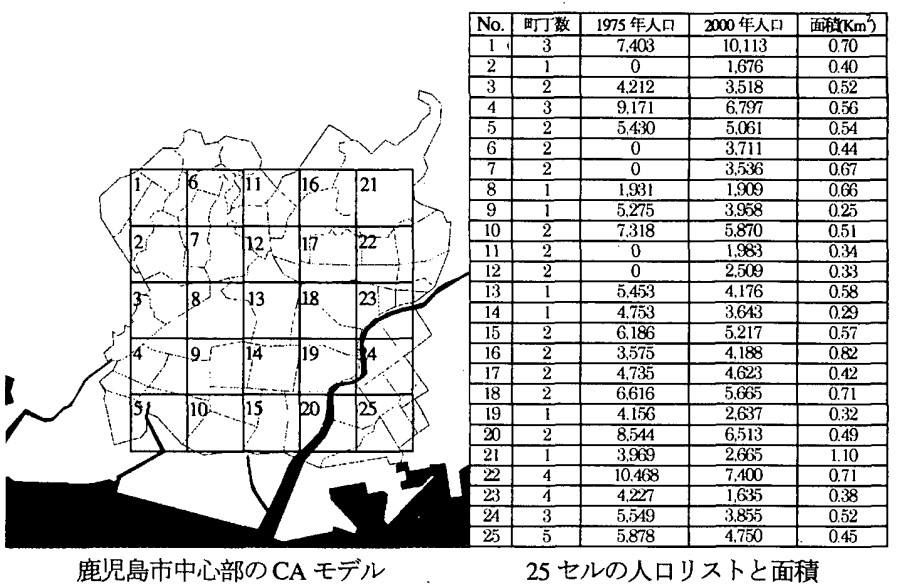

図4 鹿览島市の解析モデル

表 1 計算パラメータ一覧表

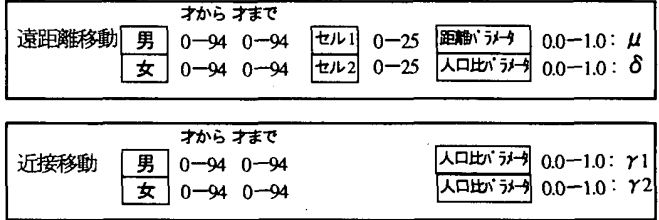

\begin{tabular}{|c|c|c|c|c|c|}
\hline \multirow{4}{*}{ 家族移動 } & \multirow{2}{*}{\begin{tabular}{c|c} 
& ‡ \\
夫 & $20-74$ \\
\end{tabular}} & & & & \\
\hline & & 雬 & $20-74$ & 移都 $5 x-4$ & \multirow{2}{*}{$\begin{array}{l}0.0-2.0: \alpha 1 \\
0.0-2.0: \alpha 2\end{array}$} \\
\hline & & 子地 & $0-59$ & 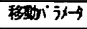 & \\
\hline & & 彩 & $35-94$ & 移政" $7 x-4$ & $0.0-2.0: \alpha 3$ \\
\hline
\end{tabular}

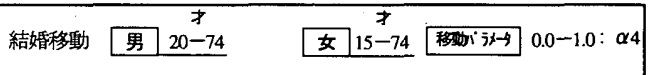

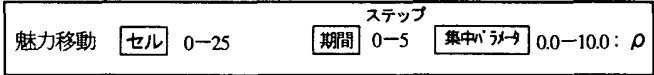

ときとは結果が大きく異なる場合がある。特に近接移動十遠距離移動あるい は十魅力移動の組合せにより、人口の分散化と集中化が同時進行する。

4.4 鹿児島市のシミュレーション

システムの単独試行及び複合試行の計算より各規則が持つ計算パラメー タの挙動性や発現強度が調べられ、その結果、パラメータの適用範囲は表 2 のように決めた。移動者の年齢層範冊炜数の組合せが考えられる。ここで は計算の一例を示す。図5は1975年鹿児島市のデータであり、初期值である。 セルの並びは図 4 に対応させる。セル内の分布図は人口ピラミッド(左 : 女, 右 : 男)であるが、20 層を表示すると見づらくなるため、10 層で表現する。 セル 2, 6, 7, 12,13 の地区は 1975 年当時開発がなされていない地域である。

5 つの近傍規則を組合せた鹿児島市の中心市街地におけるシミュレーショ ンを実行するに当たり、表 2 より 348 通りのパラメータの組合せを準備し、 パラメータによる挙動と規則による挙動を求めた。前者は同一規則内で一つ のパラメータを変化させ、一致度 凤変動を調べる。後者は使用規則のパ ラメータを固定し、規則の組合せによる評価值 $\omega^{\prime}$ の時系列変化を調べる。 結果表示ではその中で評価のよいパラメータによる規則の組合せの例である。 結果図の計算パラメータは次の通りとする。

$\mu=1.0, \delta=0.5, \gamma 1=\gamma 2=0.5, \alpha 1=\alpha 2=\alpha 3=\alpha 4=0.2, \rho=0.5$

図6 は自律規則のみ、図 7 は遠距離移動十近接移動十自律規則、図 8 は遠 距離移動十近接移動十魅力移動十自律規則、図 9 は全部規則を用いた 2000 年の結果である。図7〜9の各セル中、右上左側の数字は上段がセルの番号、 中段が式(13)で定義した一致度 $\sigma_{i}{ }^{n}$ 、下段がペナルティを与えた数である。人 ロピラミッドグラフの太線は 2000 年の現状を意味する。ステップ毎に評価值 $\omega^{l n}$ を比較すると図 10 のグラフとなる。なお、セル 6 では 1985 年から大規 
模な住宅団地開発が始まり 2000 年まで継続している。1975 年からパラメー 夕を設定すると開発前に人口の流入が始まるため、現実に合わせた計算を行 う。ペナルティの值は式(15)において、 $\lambda_{i(k, r)}^{l_{n}}>2.0$ のとき 0.01 を与えた。 図7〜9ではセル8においてペナルティを付加した層区分が多くなっている。 このセルは鹿児島大学に在籍する学生が多く住む地域であるために起こった 特殊な例である。これは学生のコンホートが常に入れ替わり、層の繰り上が りに学生人口が上の層に反映しないために起こる。このようにペナルティ付 加回数が多い場合、そのセル内で特殊な事情が内在する可能性があり、原因 調查のきっかけを与える。なお、1975 年から 1990 年までは評価值が急激に 増えている。この期間は経済の急成長期に対応していて、対象都市地域及び 周辺部の整備に伴う急激な人口の転出入があったためと考えている。

\section{5 鹿児島市の人口推移予測}

図9 の計算パラメータと 1975 年の人口データの初期値を用いて、鹿児島市 の今後の人口変動を計算した。このとき、セル 2 で大規模な住宅開発魅力事 業)を設定する。系全体の人口推移(2005 から 2015 まで)を図 11 に示す。特 に、セル 2 に対しては人口推移を図 12 に詳細に示す。男女別の年少人口、生 産年齡人口、老年人口の変動も把握することができる。もちろん単純な現状 からの近未来の予測も可能である。2000 年のデータを初期值として計算して もよい。本 CA モデルによる実務利用の都市解析では、評価值の比較的よい 幾つかの計算パラメータによる計算結果を検討することで、2005-2015 年の
表 2 複合試行で使用した計算パラメーターの範囲

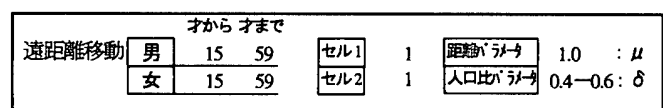

\begin{tabular}{|c|c|c|c|}
\hline \multirow{3}{*}{ 近接移動 } & \multicolumn{2}{|c|}{ 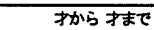 } & \\
\hline & 男 & 69 & 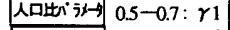 \\
\hline & 女 & 69 & 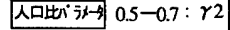 \\
\hline
\end{tabular}

\begin{tabular}{|c|c|c|c|c|c|}
\hline \multirow{4}{*}{ 家族移動 } & \multirow{2}{*}{$\begin{array}{c}7 \\
20-74\end{array}$} & & & & \multirow{4}{*}{$\begin{array}{l}0.1-0.3: \alpha 1 \\
0.1-0.3: \alpha 2 \\
0.1-0.3: \alpha 3\end{array}$} \\
\hline & & 瘶 & $20-74$ & 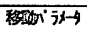 & \\
\hline & & 子供 & $0-59$ & 程 $3 x \rightarrow$ & \\
\hline & & 级 & $35-94$ & 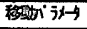 & \\
\hline
\end{tabular}

\begin{tabular}{|c|c|c|c|}
\hline 結婚移動 & 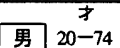 & $\begin{array}{c}\text { क } \\
\text { 女 } 15-74\end{array}$ & 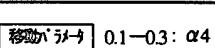 \\
\hline
\end{tabular}

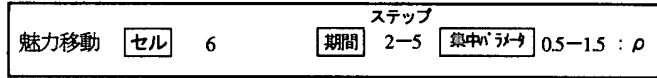

鹿児島市の中心市街の第一近似としての人口移動の傾向が把握できるものと 考える。もちろんステップが進むにつれ社会状況も変わるため、誤差は徐々 に増えると考えるべきである。なお、解析例は基本的な提案モデルの可能性 を示すため、モデル内外の人口転出入が無いものとしている。実際には大き な影響があるだろう。統計データでは 1975 年と 2000 年のデータより、鹿览 島市は約 10 万人の人口増加であった。しかし、解析モデル領域内では、増加 ではなく、逆に約 7000 人减少している。各セルの人口を見ると 1975 年当時

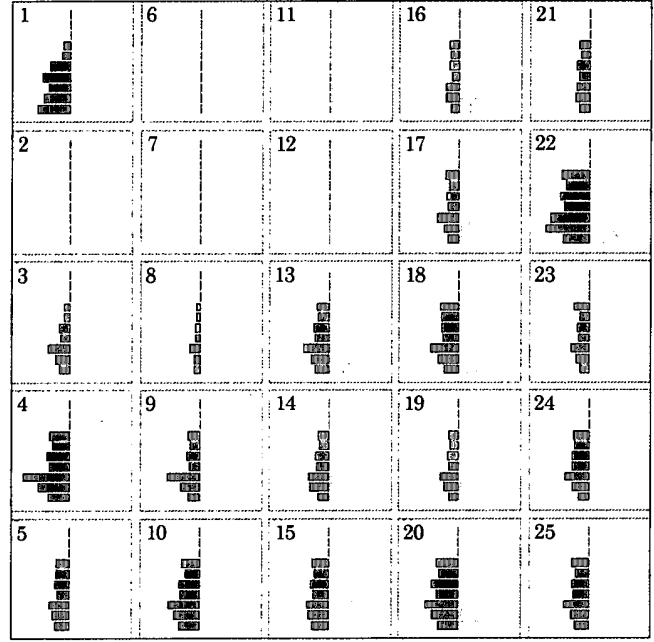

図 51975 年セル毎の鹿児島市人口分布図(初期值)

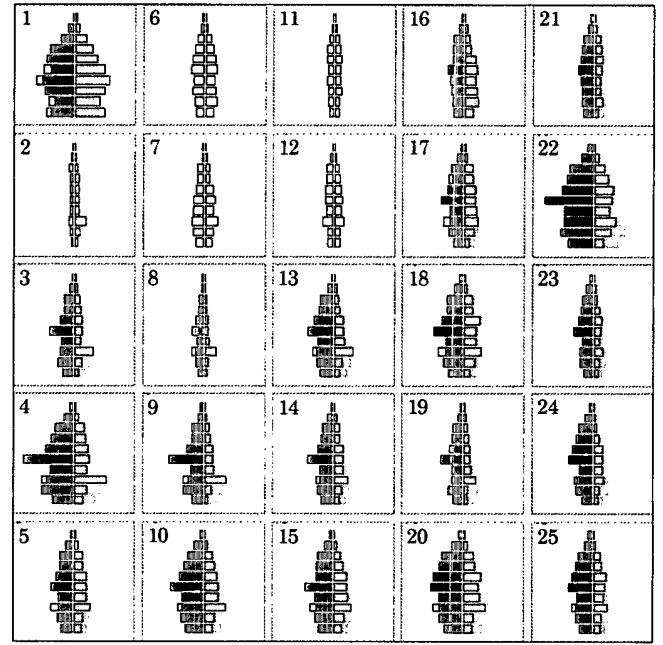

図6 自律規則のみによる2000 年の結果(太線実データ)

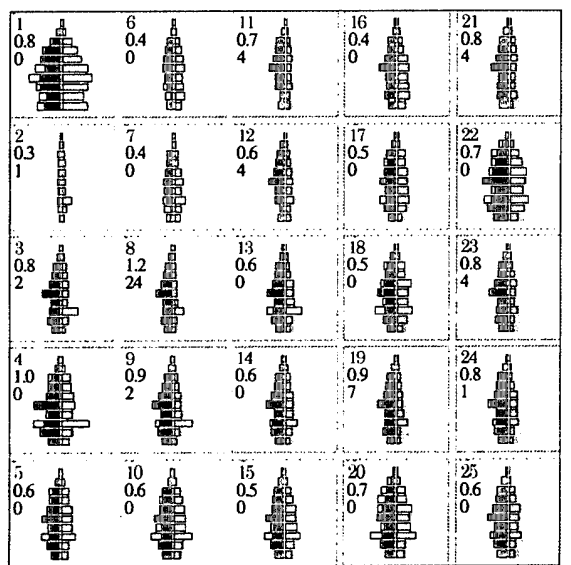

図 7 遠距離移動十近接移動十自律規則による 2000 年の結果(太線実データ) $(\mu=1.0, \delta=0.5, \gamma 1=\gamma 2=0.5)$

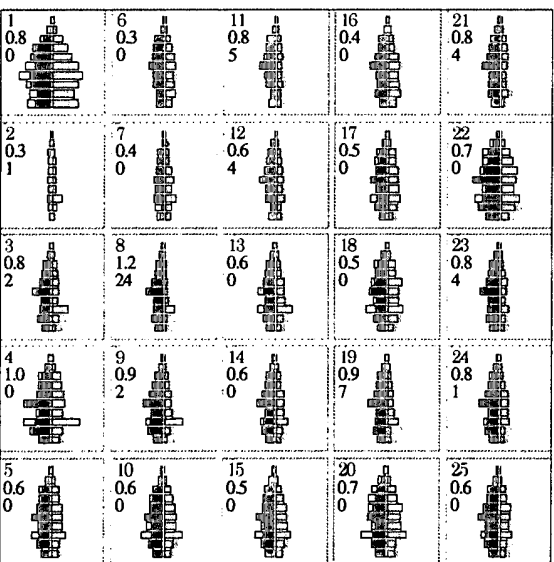

図 8 遠距離移動十近接移動十魅力移動十 自律規則による 2000 年の結果(太線実データ) $(\mu=1.0, \delta=0.5, \gamma 1=\gamma 2=0.5, \rho=0.5)$

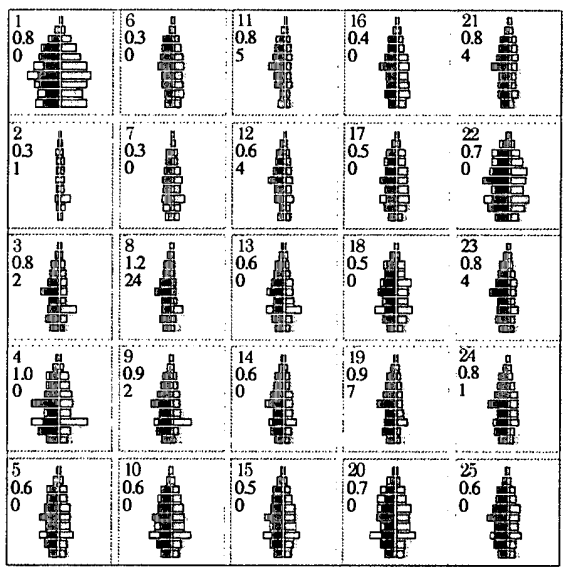

図9 全近傍規則十自律規則による 2000 年の結果(太線実データ)

$(\mu=1.0, \delta=0.5, \rho=0.5, \gamma 1=\gamma 2=0.5, \alpha 1=\alpha 2=\alpha 3=\alpha 4=0.2)$ 

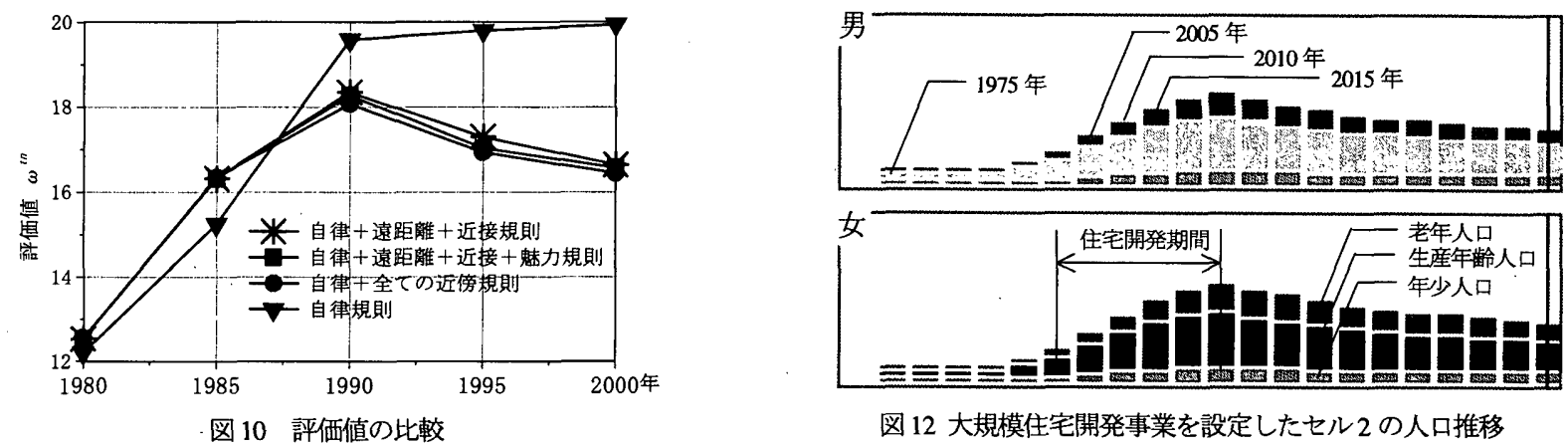

図 12 大規模住宅開発事業を設定したセル2の人口推移

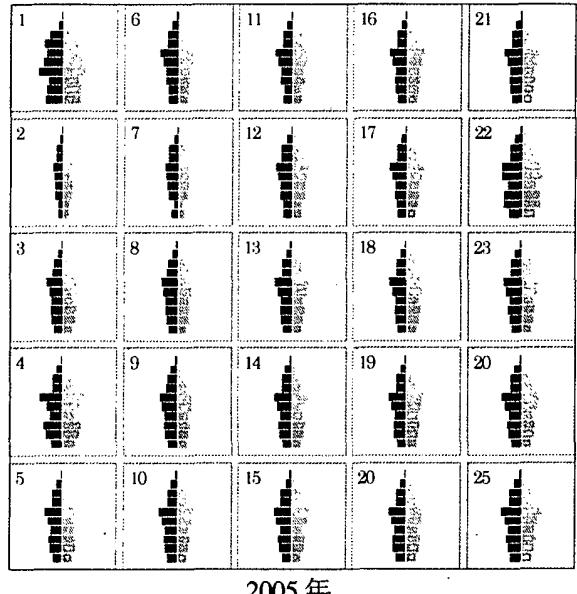

2005 年

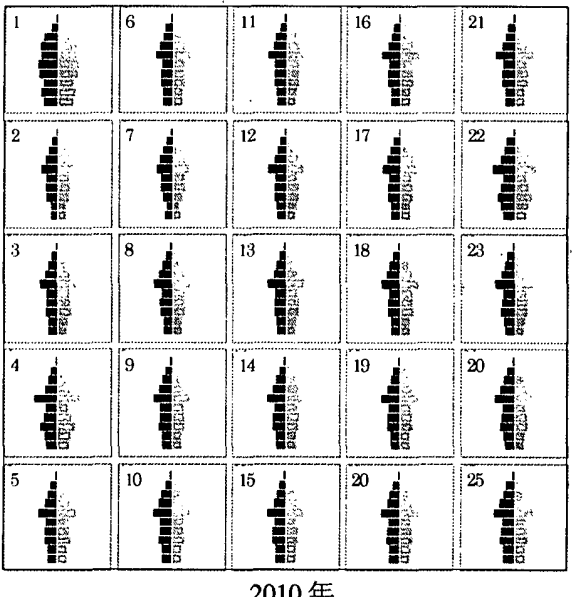

2010 年

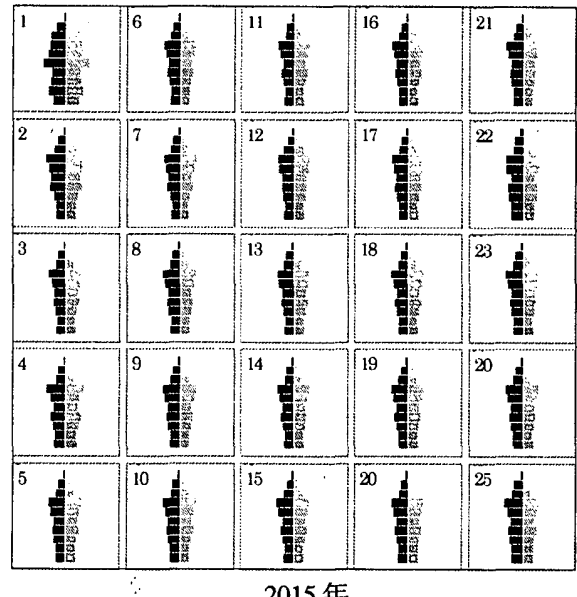

2015 年

図 11 鹿児島市の人口変動予測(セル 2 に開発事業設定) $(\mu=1.0, \delta=0.5,, \rho=0.5, \gamma 1=\gamma 2=0.5, \alpha 1=\alpha 2=\alpha 3=\alpha 4=0.2)$

集中していた人口が、2000 年には平均的に分散化されている傾向があること も図4のデータから読みとれる。また、統計データによると県外に転出した 人口も多い。このようなことから、今後、計算パラメータの同定には何らか のモデル内外の人口転出入規則を導入する必要があると判断する。

\section{5. 評価と考察}

計量地理学の観点から人口変動に注目し、自律規則と 5 つの近傍規則を設 定した CA モデルを用いて、鹿児島市を例とする小規模な地域毎の人口推計 による地方都市の解析を試みた。鹿児島市のモデルでは、系全体の人口転出 入、鹿览島大学在籍学生が住む地域等の特殊な処理などを無視したが、基本 的な考え方と解析方法の提示と提案方法により一次近似としての人口分布. 人口構造の把握ができるものと考え、種々の試行から次の知見が得られた。 (1) CAによる人口移動の規則設定は、どの地方都市にも共通寸る内容を厳選

し、できるだけ簡潔な式と少ない計算パラメータで構成すべきである。

(2) 計算パラメータの数值範用や刻み幅を決める方法は、単独試行による結果 検討に基づくとよい。

(3) 解析内容と現状と異なる地域 (予想外の変動)に対して原因究明に利用す ることができ、地域の特殊性を反映させた計画が可能である。

(4) $\mathrm{CA}$ モデル内外の人口転出入の影響は必要以上に大きいため、今後規則化 を検討すべきである。

これらの解析例と知見により CA を用いた提案手法の評価(可能性と発展性) は以下のようにまとめられる。

(1) 従来の都市全体を対象とした人口推計ではなく、地域毎の人口分布・人口 構造が調べられるため、これらの結果から実状に沿った都市・施設計画の立 案を進める基礎データの一助とすることができる。

(2) 過疎化の阻止や商業地の活性化などの具体的な都市の事象モデル
が構築でき、シミュレーション検討が可能である。

(3) 状態遷移規則と統計データより同定される計算パラメータは、解析した地 域特性(傾向)を表現する。

これらの内容は、人口変動に関する地域の状況が分かると同時に新たな規則 導入も容易であり、より現実に近い地方都市の CA モデルが構築できるフレ キシビリティと様々な条件下のシミュレーションが可能であることを意味す る。ただし、問題点も幾つかあり、以下の内容を検討しなければならない。 (1) 移動を規定する近傍規則の選定とその規則式の妥当性。

(2) セル一つの大きさと都市を評価するセル範囲決定に対する妥当性。

(3) 評価式とペナルティ設定限界值やペナルティの大きさの妥当性。

特に(3)に関しては系の内外の人口移動が平衡状態を保つと仮定したため、比 較的大きなペナルティ設定限界值2.0( $\left.\lambda_{i(k, r)}^{t_{n}}>2.0\right)$ とペナルティ值0.01を決 めた。ただし、規則設定の妥当性が確認できかつ系の再現性が高くなるに従 いここの設定限界值を小さく、ペナルティは大きな值を与えることになる。

以上の観点から、本 $\mathrm{CA}$ モデルの基本的な方法とその有効性が示せたと考 えている。ただし、問題点にも指摘したように、規則に対する変更や追加あ るいは解析領域の適用範井設定などの検討を詳紐に進める必要がある。しか し、地域性を考慮した規則化は容易ではあるものの如何に平均的で簡潔明膫 な規則を設定するかが重要になる。また、地理的条件、風土的条件の異なる 幾つかの別の地域を対象に解析・検討を実施し、本モデルの有効性を再確認し ていかなければならない。すなわち、実状に沿った都市・施設計画の立案を進 める基礎デー夕にするためには、解析データの蓄積を体系的に進めることが 肝要である。その際、地域を規則正しい格子状に区分けした基淮セルの構成 には、デー夕整理上の無䭾な作業と労力が多く発生する。今後、各地方都市 を組織的に解析していくためには、地理情報システム (Geographic information system:GIS) とリンクさせたシステム構築・開発を考えることになるだろう。 


\section{6. おわりに}

地方都市の活性化を促す都市・施設計画の方法の一つとして、CAによる地 域毎の人口分布・人口構造を追跡する数理モデルの提案を行った。計算パラメ 一タの変化により対象都市の人口分布・人口構造に近い状態が再現でき、一次 近似としての近未来が推定できる。また、都市ごとの傾向把挃ができる可能 性もあり、本モデルは都市・施設計画に一石を投じるものと考える。今後は、 データの蓄積を図り、解析結果の信頼性を確立していきたい。なお、本論の 一部は、文献 16)-18)で既に発表したものであり、全てのデータは再計算によ る結果である。

\section{参考文献}

1) 国立社会保障・人口問題研究所編: 都道府県の将来推計人口(平成 14 年 3 月推計)の概 要, http $/ / w w w . i p s s . g 0 . j p /(2002.09 .01)$

2）日本都市計画学会編：特集「人口減少·家族变動下の都市・地域計画」，都市計画，199， 1996 .

3) 染谷增男 : 住宅立地分析を用いた年龄階級別人口推定，第 23 回日本都市計画学会学 術研究論文集 $1-6,1988$

4) 加藤恭義, 光成友孝, 築山洋: セルオオトマトン法, 森北出版, 1998.10

5) White, R and Engelen, G. :Celhular Automata and urban form, Environment and Planning A 25, $1175-1193,1993$.

6) Batty,M. and Xie,Y.:Form cells to cities, Environment and Planning B: Planning and Design 21, 531-548, 1994.

7) 礼澤重志 河村廣, 谷明㬚: セルオートマトンとしての都市, 日本建築学会計画系論文 集, 506, 203-209, 1998

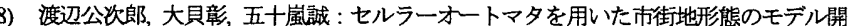
発, 日本建築学会計画系論文集 533, 105-112, 2000.

9) White, R and Engelen, G. : Cellular Automata as the basis of integrated dynamic regional modeling, Environment and Planning B: Planning and Design 24, 235-246, 1997.

10) Clarks, K. C. and Hoppen, S. : A self-modifying cellular automaton model of historical urbanization in the San Francisco Bay area, Environment and Planning B: Planning and Design, 24, 247-261, 1997.

11）奥野智江 鈴木里珠 狩野均, 加藤申子:セルオートマトンとGA 用いた仮想都市の 時系列的生成手法，人口知能学会論文誌 16(1M), 111-119, 2001.

12）㴰睪重志 河村廣, 谷明勲: 適応的マルチエージェントシステムによる都市の土地利 用パターンの形成、日本建築学会計画系論文集, 528 , 267-275, 2000

13) 石川晃: 市町杜人口推計マニュアル, 古今劃完, 1993.11.

14) 石川義孝: 人口移動的十星地理学, 古今書院, 1994.12 .

15) 伊藤達也 : 生活の中の人口学, 古今劃院, 1994.12.

16）松永安光，本間俊雄，友清貴和，豊田星二郎セル・オートマトン法を用いた地方都市 解析モデル構筑の試み その 1 (複層化セル・オートマトンモデルの提案と数理モデ ル), 日本建筑学会大会 (東京), F-1, 223-224, 2001.

17) 福永知哉, 松水安光, 本間俊雄 友清貴和、豊田星二郎,セル・オートマトン法を用いた 地方都市解析モデル構築の語み その2 (鹿览島市を例としたシミュレーション手順， 日本建筑学会大会(東京), F-1, .225-226, 2001

18）松永安光 本間俊雄 友清甹和，福永知哉 豊田星二郎、セル・オートマトン法を用い た地方都市解析モデルの評洒法日本建築学会大会(金沢) , F-1, 565-566, 2002.

\section{付録 システム開発}

シミュレーションの高速化・簡易化・視覚化を図るため、CA モデルに対する一 連の複雑な計算作業を一括して処理するコンピュータによるシステムを開発した。 上述したように多くの計算パラメータや膨大な統計データ、あるい、計算データが あるため、GUI (Graphical User Interface) を用いたユーザインターフェイスの利便性 を配慮し、対話形式で操作が行える環境を設計した。使用プログラミング言語は Microsoft Visual Basic 6.0 である。システム本体の表示と操作画面は付録漅の通りて ある。図中の番号に沿って表示内容(機能)の説明をする。

(1)セット あらかじめ指定したデータファイルに対し、リセットボタンを押すと 過去の実データ人口が初期值としてモデルの全セルに与えられる。

(2)スタートボタンこれを押すと計算が始まる。右側の欄からはシミュレ ートを何ステップ行うかの選択ができる。

(3)自動設定 あらかじめ設定した計算パラメータの範囲内で自動的に評価 計算を実行し、ファイル保存までする。

(4)保存 手動計算を実施したときのシミュレート結果を保存する。(7)(9)を BMP形式の画像とし、数值結果はTEXT形式で保存する。ファイル名之 保存場所の指定はできるようになっている。

(5)計算パラメータ設定 計算パラメータ制御ウィンドウが表示され、計算 パラメータの設定ができる(表1,2のような画面から入力する)。

(6)総人口 全セルの総人口を表示する。

(す人口分布 全セルの空間配置上で、人口ピラミッドを表示する。セルの 左上にはセル番号が表示され、(10)，(11)チェックで、次の行にセルの評 価值、最後の行にペナルティ值が表示される。セルの人ロピラミッドは 一番下の0〜9才から順番に90〜99才までの10本の横棒グラフで表示す る(左:女、右:男)。ただし、データは5才間隔で保持している。

(8)詳細データ 2つのボックスからターグットセルと表示西暦を選択し、人 ロピラミッドを表示する。

(9)経年変化 (8)で選択したセルと西暦において、人口増堿の時間変化が表 示される。時間変化は左から右に流れ、上下が各々男と女である。グラ フ途中、綎に引かれた線は(7)と(8)で表示している人口ピラミッドのステ ップ位置である。時間変化の棒グラフでは、下から年少人口、男女の生 産年齢人口、一番上が老年人口である(図12はこの画面を表示している)。 (10)評価値表示チェック チェックした後、計算すると設定した評価計算を 各ステップで行い、セルの評価値を(8)に、経年変化による評価値を(12)に 表示する。このときに(7)の表示において計算結果上に実データの人口ピ ラミッドが黒太線で表示する。

(110゚ナルティチェック チェックすると評価計算を実行時にペナルティ計 算を行う。また、(7)の表示でペナルティ数も表示する。ペナルティ付加 の条件やペナルティの大きさが設定できる。

(12)評価経過の表示 5ステップ間の評価值を表示する。(11)がチェックされる とペナルティが付加された值を表示する。
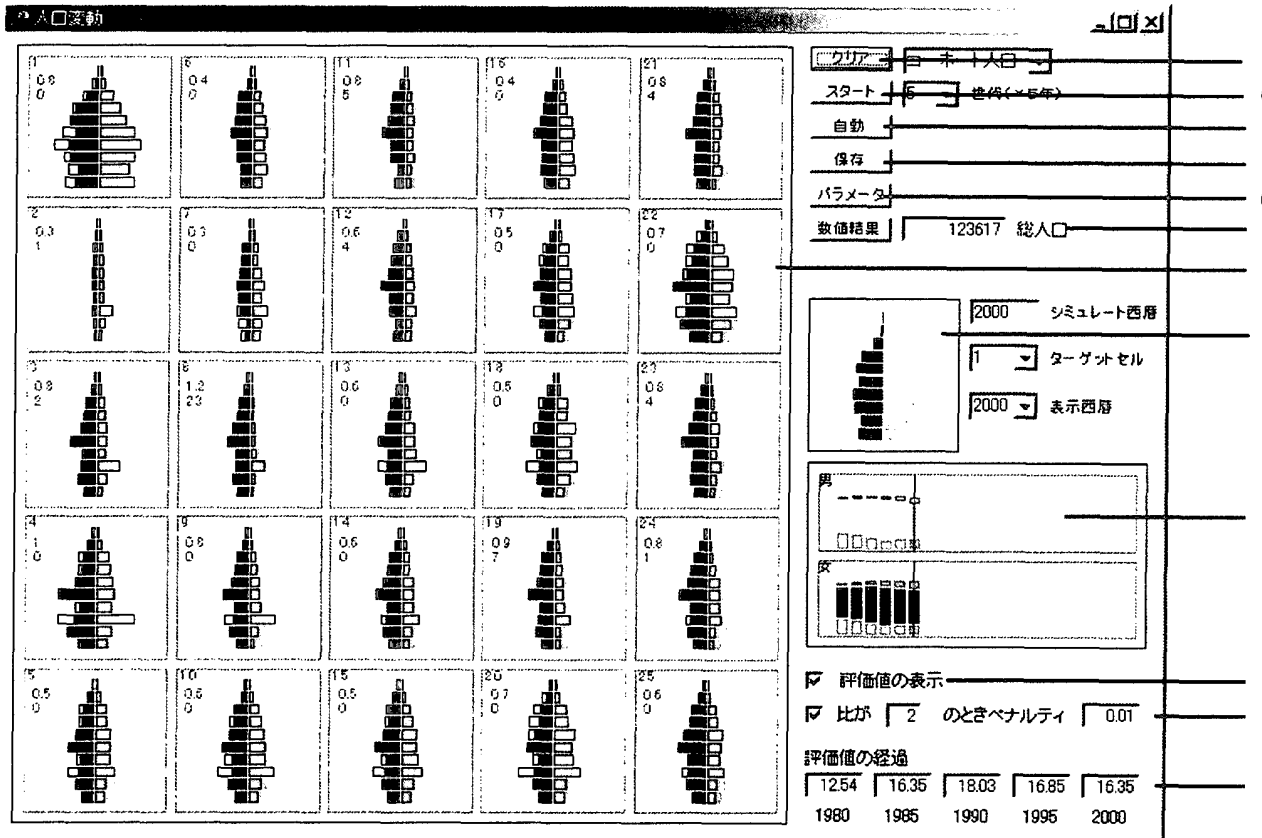

(1) リセット

(2) スタートボタン

(3) 自動設定

(4) 保存

(5) 計算パラメータ設定

(6) 総人口表示

(7) 人口分布表示(主画面)

(8) セルの詳細データ表示 セルの指定 ステップの指定

(9) セルの経年変化表示 男女別表示

付録図 開発システムのメイン画面 